\title{
Phenotypic and genotypic characteristics on calves' sale price on the western border of the state of Rio Grande do Sul, Brazil
}

\author{
Thaís Lopes Gonçalves ${ }^{1 *} \cdot$ Luciana Fagundes Christofari $^{2} \odot$ Ricardo Pedroso Oaigen ${ }^{1} \odot$ \\ Guilherme Otavio Bertodo ${ }^{1} \odot$ Júlio Otávio Jardim Barcellos ${ }^{3}$ (-) Guilherme de Medeiros Bastos $^{1}$
}

${ }^{1}$ Curso de Medicina Veterinária, Universidade Federal do Pampa (UNIPAMPA), 97501-970, Uruguaiana, RS, Brasil. E-mail: lopesg.thais@gmail.com. *Corresponding author.

${ }^{2}$ Departamento de Zootecnia e Ciências Biológicas, Universidade Federal de Santa Maria (UFSM), Palmeira das Missões, RS, Brasil.

${ }^{3}$ Departamento de Zootecnia, Universidade Federal do Rio Grande do Sul (UFRGS), Porto Alegre, RS, Brasil.

\begin{abstract}
The demand for beef cattle with specific traits is evident from sales in auctions. While purchasing, buyers consider individual traits (e.g., muscularity, frame, racial composition, and weight) as predictors of quality, and adjust their bids according to their preferences. The present study aimed to evaluate the effect of phenotypic and racial characteristics in determining the final sale price of calves of beef cattle in official auctions at the western border of the state of Rio Grande do Sul, Brazil. Five-hundred and seven lots of calves sold in calf auctions from five cities on the western border of Rio Grande do Sul were evaluated. The assignment of visual scores was based on their genetic group, frame, muscularity, and coat. Analysis of variance and the Tukey test at 5\% significance level were performed for comparing the final average prices. Variables with the greatest impact on price were the genetic group and the size of the animals. Animals of synthetic breeds obtained higher value in the three years studied and animals without racial definition showed considerable devaluation and a decrease in supply. Larger animals had less value.
\end{abstract}

Key words: added value, beef cattle, commercialization, livestock auctions, marketing.

Impacto de características fenotípicas e genotípicas no preço de venda de bezerros na fronteira oeste do Rio Grande do Sul, Brasil

RESUMO: A busca por animais com características especificas é evidenciada na comercialização em leilões, em que, ao analisar os animais, compradores consideram as características individuais (musculosidade, frame, composição racial, peso) como preditor de qualidade e ajustam seus lances conforme suas preferências. Dessa forma, o presente estudo buscou avaliar o impacto de características fenotípicas e de padrão racial na composição do preço final de venda de bezerros comercializados em feiras oficiais na fronteira oeste do Rio Grande do Sul. Foram avaliados 507 lotes de bezerros comercializados nas feiras de terneiros de cinco municípios da região da Fronteira Oeste do estado do Rio Grande do Sul. Para a atribuição de escores visuais, considerou-se grupo genético, frame, musculosidade e pelagem dos animais. Foi realizada a análise de variância e a comparação dos preços finais médios pelo teste de Tukey a 5\% de significância. As variáveis de maior impacto no preço foram grupo genético e tamanho dos animais. Animais de raças sintéticas obtiveram valorização superior nos três anos Estudados, considerável desvalorização e queda na oferta de animais sem definição racial. Os menores valores foram atribuídos a animais de tamanho grande.

Palavras-chave: agregação de valor, bovinocultura de corte, comercialização, leilões de bovinos, marketing.

\section{INTRODUCTION}

The state of Rio Grande do Sul has the sixth largest amount of beef cattle in Brazil (IBGE, 2015 ), with livestock raising corresponding to $23 \%$ of the gross value of the state's agricultural production (FEE, 2015). The western border region is noted for having the largest amount of beef cattle in the state, where this activity has strong economic, social and cultural relevance. However, over the years, the changes that have taken place in the world's economic and cultural scenarios have directly impacted the market prices of beef, causing changes in concepts and behaviors. Concerns about the product quality being offered have become evident and the market is determining what should be produced.

Changing consumer behavior has been transforming production methods and the manner in 
which production systems are examined. According to LACY et al. (2012), value-added calf production entails decisions of what and the manner in which to produce, where to sell, and when to set the price, which enables some control over sale price.

The demand for calves with specific traits is evident from sales at auctions. While purchasing, buyers consider individual traits (e.g., muscularity, frame, racial composition, and weight) as predictors of quality, and adjust their bids (BARHAM \& TROXEL, 2007) to offer different amounts for lots with distinct combinations of traits according to their business objectives (CRESPO et al, 2006). Thus, in the search for genetically superior feeder calves, visual evaluations have become the main selection method.

Several studies have demonstrated the effects of characteristics such as size (ZIMMERMAN et al., 2012; TROXEL \& GADBERRY, 2013a), racial group (TRONCOSO et al., 2012; JÚNIOR et al., 2014), coat (WILLIAMS et al., 2012), lot uniformity (ZIMMERMAN et al., 2012; CHRISTOFARI et al., 2009), and muscularity (CHRISTOFARI et al., 2008) on the final sale price of the calves. Certain characteristics are highly valued, whereas others lead to lower prices. Considering that cattle owners generate their income during the production stage, the characteristics inherent to this phase must be elucidated in order to increase their profitability, as this will affect the product quality that arrives to consumers.

The present study aimed to evaluate the impact of phenotypic and racial pattern characteristics on the final sale price of calves sold at official auctions on the western border of Rio Grande do Sul.

\section{MATERIALS AND METHODS}

In this study, 507 lots of calves sold at calf auctions from five cities on the western border of the state of Rio Grande do Sul, Brazil, were evaluated in 2014, 2015, and 2016. The evaluation was carried out in two stages by a single previously trained appraiser over the three-year period. This person examined the animals before and during the time of commercialization on the track. Before commercialization, visual scores were assigned for four characteristics (genetic group, frame, muscularity, and coat) for each of the lots. During commercialization, the lots were evaluated according to the final sale price received in Brazilian reals per kilogram of live weight $(\mathrm{R} \$ / \mathrm{kg} \mathrm{LW})$ in order to evaluate the impact of the studied characteristics on the animals' sale value.

The genetic group was determined from information presented in the catalogs made available during the auctions and from the observed racial characteristics. The calves were classified as Pure British breeds (BB), British crossbreeds (BX), Continental crossbreeds (CX), Zebu crossbreeds $(\mathrm{ZX})$, Synthetic breeds (SI), and a group with no predominant genetic background (MI).

Size, which is defined by body structure, was estimated by measuring the height of the rump at a particular age. Height of the rump is correlated with the calf's growth rate (BIF, 2016). Therefore, a wooden ruler with markings in centimeters was used for the measurement, which considered the average of the lot and the age of the calves. Animals were classified as small (less than $98 \mathrm{~cm}$ ), medium (between 99 and $108 \mathrm{~cm}$ ), or large (greater than $109 \mathrm{~cm}$ ), according to the methodology used by CHRISTOFARI et al. (2008).

According to KOURY FILHO (2009), evidence of muscle mass is used to assess muscularity. Individuals with bulkier and more convex musculature get higher scores, whereas those with less voluminous, less convex, rectilinear musculature or concavities get lower scores. Thus, the muscularity of calves was categorized into strong, medium, or weak.

Data collected was tabulated in a Microsoft Excel $^{\circledR}$ spreadsheet, and an initial exploratory data analysis was performed. The frequencies and percentages for each evaluated trait were determined. The value paid per kilogram of live weight was deflated by the General Price Index Internal Availability (IGP-DI), made available by the Economic and Statistical Foundation of Rio Grande do Sul (FEE/RS) for the month of April 2017. In the initial analysis of the data the model below was tested, as well as double, triple, and quadruple interactions among the variables, through the GLM procedure in the software SAS (1999).

$\mathrm{Y}_{\mathrm{ijklm}}=\mu+\mathrm{GR}_{\mathrm{j}}+\mathrm{TA}_{\mathrm{k}}+\mathrm{MM}_{\mathrm{l}}+\mathrm{ANO}_{\mathrm{m}}+\varepsilon_{\mathrm{ijklm}}$

Where $Y_{i j k l m}$ is the final price per kilogram of live weight of the $\mathrm{i}$-th lot, the majority are animals of the $\mathrm{j}$-th genetic group (GR), k-th animal size (TA), 1-th muscularity (MM), and $\mathrm{m}$-th year of evaluation (YEAR). $\mu$ is the overall mean of all observations, and GR is the predominant genetic group in the lot, where $\mathrm{j}$ is $\mathrm{BB}$, $\mathrm{BX}, \mathrm{CX}, \mathrm{ZX}, \mathrm{SI}$, or MI. $\mathrm{TA}_{\mathrm{k}}$ is the predominant animal size among animals in the lot, where $\mathrm{k}$ refers to small, medium, or large. $\mathrm{MM}_{1}$ is the predominant musculature among animals in the lot, where 1 is strong, medium, or weak. $\mathrm{ANO}_{\mathrm{m}}$ is the evaluated year, where $\mathrm{m}$ is 2014,2015 , or 2016. $\varepsilon_{\mathrm{ijklm}}$ is the experimental error observed for the $\mathrm{i}$-th lot, where the majority are animals of the $\mathrm{j}$-th genetic group (GR), k-th animal size (TA), l-th muscularity (MM), and $\mathrm{m}$-th year of evaluation (YEAR). 
In the analysis of the initial model, the year of evaluation was significant ( $p<0.0001)$, determining a new variance analysis and comparison of means (Tukey test at $5 \%$ of significance) within each evaluation year. There was no interaction between the model variables.

\section{RESULTS AND DISCUSSION}

The average price per kilogram of live weight $(\mathrm{R} \$ / \mathrm{Kg} \mathrm{LW})$ and the frequency of genetic group, size, muscularity, and uniformity during the years of 2014, 2015, and 2016 are listed in table 1. Crossbreeds represented $52 \%, 72 \%$, and $71 \%$ of the calves sold in 2014,2015 , and 2016, respectively. Further, only 24\%, $17 \%$, and $23 \%$ of the lots sold consisted of purebred animals in 2014, 2015, and 2016, respectively. There was a sharp decline in the group, defined as mixed in the years evaluated; in 2014, they accounted for $23 \%$, $11 \%$, and $6 \%$ of the calves sold in 2014,2015 , and 2016 , respectively.

The percentage of calves belonging to the genetic group SI $(41 \%, 46 \%$, and $45 \%)$, BB $(24 \%, 17 \%$, and $23 \%)$, and $\mathrm{BX}(11 \%, 22 \%$, and $21 \%)$ sold over the three years studied, reflect the genetic profile of the cattle from the western border of the state. ANDRADE et al. (2007) found similar results when characterizing beef cattle farmed in the state of Rio Grande do Sul, where crosses between European and Zebu breeds represented $44.8 \%$ of the sample (ZX and SI), followed by animals with no racial definition - MI (32.5\%). According to these authors, only $9.8 \%$ of the cattle were purebred animals. Through the crossbreeding, an increase in productive results is sought. Considering Rio Grande do Sul, where the cattle are predominantly of taurine origin, the introduction of zebu stock provides rusticity to the animals and incorporates important carcass characteristics, such as precocity in fat deposition and better carcass yield, made possible by heterosis (RESTLE et al., 2002).

The sharp decline (17\%) in the supply of MI calves from 2014-2016, indicated greater uniformity of the calves offered for sale and the genetic quality of the cattle. In addition, it is a sign that the regional production systems have adapted to market demands. While evaluating the commercialization of calves in Rio Grande do Sul, CHRISTOFARI (2008) reported $26.2 \%$ of lots were considered to be MI, $20 \%$ more than what was found in the present study for 2016. The observed genetic improvement of the cattle is, according to EUCLIDES FILHO (2009), due to the increasing competitiveness of demand, the greater importance given to product quality, and the production efficiency.

An assessment of the effect of genetic group on the final sale price showed no differences between SI and BB, whereas BX differed from SI only in 2014. In 2014, MI was cheaper than SI by $\mathrm{R} \$ 0.47$ per kg. In 2015 and 2016, MI was cheaper than BB by $\mathrm{R} \$ 0.53$ and $\mathrm{R} \$ 0.41$, respectively, and from SI by $\mathrm{R} \$ 0.63$ and R\$0.35, respectively. In 2016, SI and BB were significantly more expensive than $\mathrm{CX}$ which represented only $5 \%$ of the lots offered for sale.

Table 1 - Average sale price of calves deflated per $\mathrm{kg}$ of live weight ( $\mathrm{R} \$ \mathrm{Kg} \mathrm{LW})$, frequency (\%) and standard deviation (SD) according to the genetic group size, and muscularity of lots traded in auctions in the years of 2014. 2015, and 2016 in the western border of Rio Grande do Sul, Brazil.

\begin{tabular}{|c|c|c|c|c|c|c|c|}
\hline \multirow[b]{2}{*}{ Variable } & & \multicolumn{2}{|c|}{---------------2014--------------- } & \multicolumn{2}{|c|}{--------------2015--------------- } & \multicolumn{2}{|c|}{-------------2016------------- } \\
\hline & & $\begin{array}{l}\text { Average Price } \\
(\mathrm{R} \$ / \mathrm{kg} \mathrm{LW})^{*}\end{array}$ & $\mathrm{SD}$ & $\begin{array}{l}\text { Average Price } \\
(\mathrm{R} \$ / \mathrm{kg} \mathrm{LW})^{*}\end{array}$ & $\mathrm{SD}$ & $\begin{array}{l}\text { Average Price } \\
(\mathrm{R} \$ / \mathrm{kg} \mathrm{LW})^{*}\end{array}$ & $\mathrm{SD}$ \\
\hline \multirow{5}{*}{ GENETIC GROUP $^{* *}$} & SI & $6.05^{\mathrm{a}}(41 \%)$ & 0.59 & $6.87^{\mathrm{a}}(46 \%)$ & 0.44 & $6.27^{\mathrm{a}}(45 \%)$ & 0.32 \\
\hline & BB & $5.80^{\mathrm{ab}}(24 \%)$ & 0.25 & $6.77^{\mathrm{a}}(17 \%)$ & 0.69 & $6.33^{\mathrm{a}}(23 \%)$ & 0.43 \\
\hline & $\mathrm{BX}$ & $5.63^{b}(11 \%)$ & 0.33 & $6.55^{\mathrm{ab}}(22 \%)$ & 0.66 & $6.15^{\mathrm{ab}}(21 \%)$ & 0.24 \\
\hline & MI & $5.58^{\mathrm{b}}(23 \%)$ & 0.40 & $6.24^{\mathrm{bc}}(11 \%)$ & 0.50 & $5.92^{\mathrm{b}}(6 \%)$ & 0.38 \\
\hline & $\mathrm{CX}$ & - & - & $6.57^{\mathrm{abc}}(4 \%)$ & 0.39 & $5.82^{\mathrm{b}}(5 \%)$ & 0.21 \\
\hline \multirow{3}{*}{ SIZE } & Small & $5.97^{\mathrm{ab}}(10 \%)$ & 0.38 & $6.73^{\mathrm{ab}}(14 \%)$ & 0.80 & $6.27^{\mathrm{ab}}(23 \%)$ & 0.45 \\
\hline & Medium & $5.80^{\mathrm{ab}}(63 \%)$ & 0.54 & $6.77^{\mathrm{b}}(64 \%)$ & 0.57 & $6.22^{\mathrm{ab}}(56 \%)$ & 0.32 \\
\hline & Large & $5.85^{\mathrm{ab}}(28 \%)$ & 0.41 & $6.50^{\mathrm{a}}(22 \%)$ & 0.36 & $6.12^{\mathrm{ab}}(21 \%)$ & 0.34 \\
\hline \multirow{3}{*}{ MUSCU-LARITY } & Strong & $5.99^{\mathrm{ab}}(12 \%)$ & 0.46 & $6.71^{\mathrm{ab}}(17 \%)$ & 0.69 & $6.11^{\mathrm{ab}}(10 \%)$ & 0.23 \\
\hline & Medium & $5.82^{\mathrm{ab}}(84 \%)$ & 0.49 & $6.72^{\mathrm{ab}}(65 \%)$ & 0.55 & $6.23^{\mathrm{ab}}(69 \%)$ & 0.35 \\
\hline & Weak & $5.57^{\mathrm{ab}}(4 \%)$ & 0.45 & $6.53^{\mathrm{ab}}(18 \%)$ & 0.54 & $6.19^{\mathrm{ab}}(21 \%)$ & 0.42 \\
\hline
\end{tabular}

*Different letters differ statiscatically $(\mathrm{P}$-value $<0.05)$ by the Tukey test. ${ }^{* *}$ SI means Synthetic breeds, BB means Pure British breeds, BX means British crossbreeds, MI means no predominant genetic background, and CX means Continental crossbreeds. 
During the three years studied, the supply of MI calves was lower and was the least valued by buyers, as can be seen in the sale prices (Table 1). This indicates the needs of consumers and contributes to a strategy for adding value to the product through racial definition of the offered animals.

The average muscularity of the lots did not differ significantly between the groups in the period studied. However, a tendency to attribute greater value to calves with medium and strong musculatures was observed. This trait, despite being influenced by environmental factors (PONS, 1989; JORGE JUNIOR et al., 2001), is of high commercial significance for beef cattle because it is related to the amount of meat that can be produced by the animal, thereby indicating carcass quality and productivity.

A study on the genetic association between visual scores showed that the selection for conformity for yearlings (amount of meat as measured by length, body depth, and muscle development) affected characteristics of average daily weight gain or speed of weight gain at weaning and over a year of age (EVERLING et al., 2012).

Furthermore, muscularity is correlated with price, since higher priced animals exhibit greater development of muscle mass (KOURY FILHO et al., 2009). Thus, the commercial preference for calves showing good muscularity instead of weight alone suggested a change of calf production and selection based on market demands, which might allow producers to add value to the calves offered for sale by employing genetic improvement technologies.

The frame size of calves is used to estimate their size as adults. This characteristic is directly related to the breed, where cattle of taurine origin (Bos taurus) tend to exhibit lower rump height than that in Bos indicus. However, cattle with small or very large frames are avoided irrespective of their racial groups. Vargas et al. (1998) obtained a high genetic correlation between age at puberty and rump height, with taller heifers entering puberty at a later age.

Cattle with small frames reach selling weight in less time but have less carcass yield. Nevertheless, in scenarios with lower nutrient availability, smaller heifers can reach puberty earlier than the ones with larger frames (BARCELLOS, 2001). Therefore, this trait should be taken into account when purchasing feeder cattle, regardless of sex or the objective of the production system. It is likely to have high importance in regions where there are restrictions in the food supply.

In the present study, the average sale of medium-sized calves in 2015 was greater than large calves by $\mathrm{R} \$ 0.27$, and by $\mathrm{R} \$ 0.04$ over small calves. In 2014 and 2016, lots with small calves had slightly higher prices. Results reported in this study differ from those obtained by TROXEL \& GADBERRY (2013b), where small animals were worth less, and by SCHROEDER et al. (1988) who observed a strong preference for larger animals. However, currently, costs for rearing and fattening excessively large animals generate unsatisfactory margins, thus there is a preference for animals of moderate size.

The production system taking into account characteristics of race, size, and muscularity demanded by the market allows offering uniform lots (CHRISTOFARI et al., 2009). They represent a product with uniform quality because animals with similar characteristics are indicators of carcasses with similar characteristics. Therefore, uniform lots can be better remunerated.

The oscillation of the value of calves could be attributed to a complex set of variables, for example, whether or not females are being slaughtered. From 2011 to 2014, the number of females slaughtered was above 40\% (IBGE, 2016), thereby reducing the supply of calves and raising prices after 2013. The worst exchange ratio happened in 2015 when a steep decline in female slaughtering occurred (IBGE 2016) as a result of breeding cow retention and replenishment via feeder cattle, causing an inversion of the supply and demand cycle and a decrease in prices, as observed in 2016.

The economic value of an animal results from a number of desirable traits that influence its economic performance (ARTMANN et al, 2014). There are several factors that determine the sale price of feeder cattle; however, the buyers can only base their choice on the correlation that they believe exist between the characteristics observed in live cattle and meat quality (TRONCOSO et al, 2012).

In addition, an adaptation of the productive systems is essential for the development of sustainable livestock, defined by JACK (2009) as an advance of changes and market support. This way, changes based on consumer's preferences will define an acceptance of the product and the longevity of the business.

Demand for livestock reflects the preferences for specific characteristics, and supply works accordingly by adapting the lots to the buyers' preferences (SCHROEDER et al., 1988; CRESPO et al., 2006). Thus, the marketing strategy regarding racial pattern, uniformity, muscularity, and size is not dissociated from the quality of the offered product, therefore being beneficial for both the cattle owners and the consumers.

In addition, in a conventional market, the price of calves is not able to cover costs due to 
the low profit margins during the maturation phase. Therefore, attending to market niches that pay more becomes an alternative that impacts the economic results of the activity.

In an increasingly competitive and demanding market, calf production should be geared towards producing animals with genetic quality, standardization and compliance with parameters established by the market. This will allow producers to be competitive and have good profitability in times of oscillations and high production costs.

Although in a scenario with low cattle supply and high demand, where buyers have limited choices, it can be observed from this study that certain characteristics are better remunerated. Having that knowledge is useful during inversions of the livestock cycle because it becomes crucial to be competitive. However, there are variables that were not mentioned in this study that may also play a role in the composition of the feeder animals' sale price. Some of them are: order of entry, number of animals per lot, bank loans, sex and weight of the animals. However, this study evaluated the impact of characteristics that can be manipulated by cattle owners through genetic improvement and will help in the decision marketing process of productive systems.

\section{CONCLUSION}

The price per kilogram of live weight was higher for calves from the SI and European groups, small and medium-sized animals, good muscle definition, and uniformity. These characteristics were important determinants of the price per $\mathrm{kg}$ $\mathrm{LW}$, reflecting the preference of buyers. Therefore, the variables presented can be used as criteria for selecting calves at auctions, notwithstanding the environmental influence. These characteristics are good indicators of production performance. In addition, the correct selection of calves has a direct effect on the costs incurred by the production system. Therefore, it is useful to categorize the products to increase its competitiveness in the market.

\section{DECLARATION OF CONFLICTING INTERESTS}

The authors declare that they have no conflict of interest.

\section{REFERENCES}

ANDRADE, M.L et al. Caracterização socioeconômica e produtiva da bovinocultura de corte no estado do Rio Grande do Sul. Revista Estudo e Debate. v. 14,p. 95-125,2007.Available from: $<$ https://www.researchgate. net/profile/Adalberto_Netto/publication/237602181_Caracterizacao_ socioeconomica_e_produtiva_da_bovinocultura_de_corte_no_estado_ do Rio Grande do Sul1/links/5548e6aa0cf25a87816aaad9.pdf>. Accessed: Jan. 20, 2017.

ARTMANN, T.A. et al. Breeding and cattle $1 / 2$ blood taurino $x 1 / 2$ blood zebu in brazil. Revista Científica de Medicina Veterinária. v. 22, p. 1-20, 2014. Available from: $<$ http://faef.revista.inf.br/imagens arquivos/arquivos_destaque/ccp0nNwfzVgRuEI_2014-2-8-9-42-2. pdf>. Accessed: Aug. 10, 2017.

BARCELlOS, J.O.J. Puberdade em novilhas Braford: desenvolvimento corporal e relações endócrinas. 2001. 164f. Tese (Doutorado em Zootecnia) - Faculdade de Agronomia/Universidade Federal do Rio Grande do Sul, Porto Alegre. Accessed: Jan. 20, 2017.

BARHAM, B. L.; TROXEL, T. R. Factors affecting the selling price of feeder cattle sold at Arkansas livestock auctions in 2005. Journal of Animal Science, v. 85, p. 3434-3441, 2007. Available from: <https:// doi.org/10.2527/jas.2007-0340>. Accessed: Jan.18, 2017. doi: 10.2527/ jas.2007-0340.

BEEF IMPROVEMENT FEDERATION (BIF) Guidelines for Uniform Beef Improvement Programs. 2016. p. 17-20. Available from: <https://beefimprovement.org/wp-content/uploads/2013/07/ BIFGuidelinesFinal_updated0916.pdf $>$. Accessed: Nov. 10, 2016.

CHRISTOFARI, L.F. et al. Tendency in the commercialization of calves in Rio Grande do Sul related to your genetic characteristics. Revista Brasileira de Zootecnia, v. 37, p.171-176, 2008. Available from: $<$ http://dx.doi.org/10.1590/S1516-35982008000100025>. Accessed: Jan. 23, 2017. doi: 10.1590/S1516-35982008000100025.

CHRISTOFARI, L.F. et al. Manejo da comercialização em leilões e seus efeitos no preço de bezerros de corte. Revista Brasileira de Zootecnia. v. 38 , p. $196-203$, 2009. Available from: $<\mathrm{http} / / / \mathrm{dx}$. doi. org/10.1590/S1516-35982009000100024>. Accessed: Jan. 23, 2017. doi: $10.1590 / \mathrm{S} 1516-35982009000100024$.

CRESPO, B. L. et al. Variabilidad de corto plazo en la formación de precios em el mercado vacuno de reposición. Instituto Nacional de Investigación Agropecuaria (INIA). Serie técnica. N. 155, 2006. Available from: <http://www.ainfo.inia.uy/digital/bitstream/ item/2900/1/111219240807150227.pdf>. Accessed: Jan. 23, 2017.

EUCLIDES FILHO, K. Evolução do melhoramento genético de bovinos de corte no Brasil. Revista Ceres, v. 56, p. 620-626, 2009. Available from: $<$ http://www.redalyc.org/pdf/3052/305226893010. pdf $>$. Accessed: Aug. 10, 2017.

EVERLING, D. M et al. Associação genética de escores de conformação com características de crescimento em bovinos da raça Angus. Pesquisa agropecuária brasileira, v. 47, p. 1524-1532, 2012. Available from: $<$ http://www.scielo.br/pdf/pab/v47n10/16.pdf $>$. Accessed: Jan. 23, 2017.

FUNDAÇÃODEECONOMIAEESTATÍSTICASIEGFRIEDEMANUEL HEUSER (FEE). PIB Estadual. Porto Alegre, 2015. Available from: $<$ http:// www.fee.rs.gov.br/wp-content/uploads/2015/11/20160414tabela-pibestadual-sh-2010-2015.xlsx>. Accessed: Aug. 7, 2017.

INSTITUTO BRASILEIRO DE GEOGRAFIA E ESTATÍSTICA (IBGE) Estatística da Produção Pecuária. 2016. Available from: $<$ https://biblioteca.ibge.gov.br/visualizacao/periodicos/2380/ epp_2016_mar.pdf>. Accessed: Aug. 19,2017.

INSTITUTO BRASILEIRO DE GEOGRAFIA E ESTATÍSTICA (IBGE). Pesquisa Pecuária Municipal. Rio de Janeiro, 2015. 
Available from: <http://www.sidra.ibge.gov.br/bda/tabela/listabl. asp? $\mathrm{z}=\mathrm{t} \& \mathrm{o}=24 \& \mathrm{i}=\mathrm{P} \& \mathrm{c}=3939>$. Acessed: Aug. 10, 2017.

JACK. L. Sustainable Change and Benchmarking in the Food Supply Chain In: _. Benchmarking in Food and Farming: Creating Sustainable Change. New York: Gower, 2009. p.1-8. Accessed: Aug. 12, 2017.

JORGE JUNIOR, J. et al. Influence of Some Environmental Effects on Visual Scores of Conformation, Precocity and Musculature Measured at Weaning in Nelore Cattle. Revista. Brasileira de Zootecnia, v. 30, p. 1697-1703, 2001. Available from: <http://dx.doi.org/10.1590/ S1516-35982001000700006>. Accessed: Jan. 23, 2017. doi: 10.1590/ S1516-35982001000700006.

JÚNIOR. C. K. et al. Phenotypic factors and genetic group on the selling price formation of beef calves sold in auctions at the Northern region of Paraná State, Brazil. Ciência Rural, v.44, p.752-756, 2014. Available from: $<$ http://dx.doi.org/10.1590/S0103-84782014000400030>. Accessed: Jan. 23, 2017. doi: 10.1590/S0103-84782014000400030.

KOURY FILHO, W. et al. Estimativas de herdabilidade e correlações para escores visuais, peso e altura ao sobreano em rebanhos da raça Nelore. Revista Brasileira de Zootecnia, v. 38, p. 2362-2367, 2009. Available from: <http://dx.doi.org/10.1590/S1516-35982009001200010>. Accessed: Jan. 23, 2017. doi: 10.1590/S1516-35982009001200010.

LACY, R.C. et al. Profitable cattle marketing for the Cow-Calf Producer. University of Georgia Cooperative Extension Bulletin (Boletim). n. 1078, 2012. Available from: <http://extension.uga.edu/ publications/detail.html?number=B1078>. Accessed: Jan. 23, 2017.

RESTLE, J. et al. Breed and Heterosis Effects on Carcass Quantitatives Traits of Feedlot Finished Cull Cows. Revista Brasileira de Zootecnia, v.31, p.350-362, 2002. Available from: <http://www.scielo.br/pdf/rbz/ v31n1s0/10315.pdf $>$. Accessed: Aug. 12, 2017.

SCHROEDER, T. et al. Factors affecting Feeder Cattle Price Differentials. Western Journal of Agricultural Economics. v.13, p. 71-81, 1988. Available from: <http://ageconsearch.umn.edu/ bitstream/32161/1/13010071.pdf>. Accessed: Jan. 23, 2017.

TRONCOSO, J.L. et al. Factors that influence the price of cattle in livestock auctions: the case of the stockyard of Melipilla (Chile). Ciencia e investigación agraria. v. 39, p.37-45, 2012. Available from: <http://dx.doi.org/10.7764/rcia.v39i1.77>. Accessed: Jan. 23, 2017. doi: 10.7764/rcia.v39i1.77.

TROXEL T.R, GADBERRY M.S. Population and price differences for Arkansas sale barn marketed calves from 2000 to 2010 due to genetically influenced phenotype. Arkansas Animal Science Department Report. n 612, p.81-87, 2013a. Available from: <https://animal-science.uark.edu/ news_enews_pubs/research_report.php $>$. Accessed: Jan. 23, 2017.

TROXEL T.R, GADBERRY M.S. Comparing the factors affecting the selling price of beef calves soldat Arkansas livestock auctions during a declining cattle inventory. The Professional Animal Scientist. v.29, p. $652-664,2013$ b. Available from: $<$ https://doi.org/10.15232/S10807446(15)30297-7>. Accessed: Aug. 12, 2017. doi: 10.15232/S10807446(15)30297-7.

VARGAS, C.A. et al. Estimation of genetic parameters for scrotal circumference, age at puberty in heifers, and hip height in Brahman cattle. Journal of Animal Science, v.76, p.2536-2541, 1998. Available from: <http://animal.ifas.ufl.edu/elzo/publications/refereed/ docs/1998_2_vargas.pdf $>$. Accessed: Jan. 23, 2017.

WILLIAMS. G.S. et al. Determinants of price differentials in Oklahoma Value-Added Feeder Cattle Auctions. Journal of Agricultural and Resource Economics. v. 37, p. 114-127, 2012. Available from: <http:// www.jstor.org/stable/23243052>. Accessed: Jan. 23, 2017.

ZIMMERMAN, L. C. et al. "The effect of Value-Added Management on Calf Prices at Superior Livestock Auction Video Markets" Journal of Agricultural and Resource Economics. v.37, p.128-143, 2012. Available from: <http://www.jstor.org/stable/23243053>. Accessed: Jan. 22, 2017. 